\section{Anti-Inflammatory Effects of Resveratrol and Related Polyphenols Contribute to their Potential Beneficial Effects in Aging}

\author{
Selena K Tavener and Kiran S Panickar* \\ Science \& Technology Center, Hill's Pet Nutrition Center, Topeka, Kansas, \\ USA
}

\begin{abstract}
Resveratrol is a polyphenol found in grapes, blueberries, mulberry and raspberry. Due to its antioxidant, anti-inflammatory, anti-microbial and anti-proliferative properties resveratrol has been reported to have health benefits in aging and age-related health disorders. While the actions of resveratrol and related polyphenols are likely multifactorial, the anti-inflammatory of polyphenols are reasonably well documented. Most studies demonstrating efficacy with resveratrol have been conducted in animal models or in vitro models. In human trials some promising effects of resveratrol have been reported for several health conditions including cancer, dementia, inflammatory bowel syndrome, arthritis, ulcer and dermatological disorders. The molecular mechanisms underlying resveratrol's anti-inflammatory effects include signaling pathways mediated by NFKB, Akt, JAK/ STAT and sirtuins and also a reduction in pro-inflammatory cytokine production. The antioxidant effects of resveratrol involve reducing Reactive Oxygen Species (ROS) and malondialdehyde levels, or conversely increasing levels of antioxidant enzymes superoxide dismutase, catalase and glutathione peroxidase. Review of all agingassociated health conditions is beyond the scope of this article. We will, therefore, focus on the effects of resveratrol and other stilbenoids on selected areas of health including immune function, renal function and cognitive function from animal and human studies in aging.
\end{abstract}

Keywords: Canines; Felines; Glomerulus; Immune; Memory; Polyphenol

* Corresponding author: Kiran S Panickar, Science \& Technology Center Hill's Pet Nutrition Center, Topeka, Kansas, USA, Tel: +1 7852868002; E-mail: kiran_panickar@hillspet.com

Citation: Tavener SK, Panickar KS (2020) Anti-Inflammatory Effects of Resveratrol and Related Polyphenols Contribute to their Potential Beneficial Effects in Aging. J Food Sci Nutr 6: 079.

Received: September 26, 2020; Accepted: October 09, 2020; Published: October 20, 2020

Copyright: ( 2020 Tavener SK, et al. This is an open-access article distributed under the terms of the Creative Commons Attribution License, which permits unrestricted use, distribution, and reproduction in any medium, provided the original author and source are credited.

\author{
Abbreviations \\ BDNF: Brain-derived neurotrophic factor \\ C5: Complement 5 \\ CCL2: Chemokine (C-C motif) ligand 2 (aka MCP-1) \\ $\mathrm{CD}$ : Cluster of differentiation \\ COX-2: Cyclooxygenase-2 \\ CRP: C-reactive protein \\ CXCL10: C-X-C motif chemokine 10 \\ FOXO: Forkhead transcription factor \\ GM-CSF: Granulocyte-macrophage colony-stimulating factor \\ HSP70: Heat shock protein 70 \\ ICAM-1: Intercellular adhesion molecule 1 \\ IFN- $\gamma$ : Interferon-gamma \\ iNOS: Inducible nitric oxide synthase \\ IL-6: Interleukin-6 \\ JAK/STAT: Janus kinase/Signal transducer and activator of \\ transcription \\ JNK: c-Jun N-terminal kinase \\ LPS: Lipopolysaccharide \\ MAPK: Mitogen-activated protein kinase \\ MCP-1: Monocyte chemoattractant protein -1 \\ MIP- $\alpha$ : Macrophage inflammatory protein-1 alpha \\ miR: microRNA \\ NAD: Nicotinamide adenine dinucleotide \\ NFkB: Nuclear factor kappa B \\ NK: cells Natural killer cells \\ PBMC: Peripheral blood mononuclear cell \\ PGE2: Prostaglandin E2 \\ PI3K: Phosphoinositide 3-kinase \\ PKC: Protein kinase C \\ ROS: Reactive oxygen species \\ SIRT1: Sirtuin1 \\ TNF- $\alpha$ : Tumor necrosis factor-alpha \\ SOD2: Superoxide dismutase 2
}

\section{Introduction}

Resveratrol is a stilbene polyphenol found in grapes and other plants with demonstrated anti-inflammatory effects. The antiinflammatory effects of resveratrol in various adverse health conditions have been reviewed [1]. The beneficial effects of resveratrol likely are not solely due to its anti-inflammatory actions but rather a combined wide-ranging effect including antioxidant, anti-tumor and anti-proliferative actions. The antioxidant effects of resveratrol have been well documented (see [2] for review) and stilbenoids in general exert several biological activities ranging from cardioprotection, neuroprotection, anti-inflammation, anti-microbial and anti-tumor properties [3-5].

One of the important signaling pathways reported for resveratrol is the activation of sirtuins, a member of the NAD $(+)$-dependent 
enzymes, or sirtuin-activated pathways [6]. In Human Airway Smooth Muscle Cells (HASMCs) taken from patients with chronic obstructive pulmonary disease, lipoteichoic acid-induced cytokine/ chemokine release was attenuated by resveratrol including a decrease in CCL-2, IL-6, IL-8 and GM-CSF, likely mediated through the activation of SIRT1 [7]. Resveratrol decreased LPS and nicotineinduced cytotoxicity in human gingival fibroblasts by decreasing ROS and PGE2 production, as well as the expression of COX-2 through activating SIRT1 and mediated by the decline in PKC, PI3K, MAPK and NFאB pathways [8]. Other intracellular signaling pathways that may or may not be mediated by sirtuins have also been reported. The anti-inflammatory effects of resveratrol have been reported in many cell types and several signaling molecules have been identified in its anti-inflammatory actions. When murine microglial (C8-B4), macrophage (RAW264.7) and Neuronal-like (Neuro2a) cell lines were stressed with pro- inflammatory stimuli including Lipopolysaccharide (LPS) and Interferon- $\gamma$ (IFN- $\gamma$ ), resveratrol was an inhibitor of nitric oxide and pro-inflammatory cytokine release in these cells [9]. Rat hepatocytes isolated and cultured and then stimulated with interleukin- 1 and interferon- $\gamma$ along with varying concentrations of resveratrol showed that resveratrol decreased the cytokine-induced iNOS expression, possibly through up-regulation of the JNK-signaling pathway [10]. In Human Coronary Artery Smooth Muscle Cells (HCASMCs), resveratrol reduced both basal and IFN$\gamma$-stimulated levels of levels of MCP-1, IL- 6 and IL-8 by attenuating ERK activity [11]. Activation of SIRT1 through resveratrol in RINm5F cells (pancreatic islet cell line) or isolated rat islets also prevented the pro-inflammatory stress induced by IL- $1 \beta$ and IFN- $\gamma$ by inhibiting iNOS and nitric oxide production likely through the inhibition of the inhibition of the NFאB signaling pathway [12]. Liu et al. [13], investigated the molecular basis of the effects of resveratrol on TNF- $\alpha$-induced ICAM-1 expression in Human Umbilical Vein Endothelial Cells (HUVECs) and they found that resveratrol attenuated endothelial inflammation by reducing ICAM-1 expression and that the protective effect was mediated partly through the miR221/222/AMPK/p38/NFkB pathway. Subedi et al. [14], reported that the extract of resveratrol-enriched rice developed through genetic engineering techniques, also showed robust anti-inflammatory effects in LPS-activated BV-2 murine microglial cells by inhibiting the expression of iNOS, COX-2 and inhibiting the NFאB- pathway. Even in the absence of resveratrol, activation of SIRT1 by any other means has been documented to have anti-inflammatory effects lending support to the hypothesis that one of the anti-inflammatory mechanisms of resveratrol may be through activating sirtuins. Yoshizaki et al. [15], showed that the gene expression profiles in 3T3-L1 adipocytes by SIRT1 activators was inversely related to inflammatory gene expression and an attenuation of TNF- $\alpha$-induced insulin resistance. While resveratrol does not act exclusively through activation of SIRT1, it is conceivable that some of the actions of SIRT1 activators may be relevant to the anti-inflammatory actions of resveratrol as well.

Other stilbenes, besides resveratrol, have also been reported to have anti-inflammatory properties. Extract of Artocarpus lakoocha, traditionally used in Thai medicine, is high in stilbenoids, especially oxyresveratrol. In RAW 264.7 murine macrophage cell line, this extract attenuated the LPS-induced increase in iNOS and COX2, through blocking the PI3K/Akt pathway [16]. Piceatannol, a stilbene with a chemical structure similar to resveratrol, also inhibits inflammation induced by TNF- $\alpha$ by attenuating the NFKB signaling pathway in KBM-5 cells [17-18]. In propionibacterium acnes-stimulated human keratinocyte cell line HaCaT, piceatannol alleviated proliferation and migration of keratinocytes through its anti-inflammatory properties by blocking the NFkB pathway [19], indicating that one possible mechanism of the anti-inflammatory action of some stilbenoids may be through attenuating the $\mathrm{NF \kappa B}$ pathway (see [20] for review). Combretastatins are dihydrostilbenoids found in the bark of Combretum caffrum, a South African bushwillow tree. Several bioactive stilbenes (combretastatins A series), dihydrostilbenes (combretastatins B series), phenanthrenes (combretastatins $\mathrm{C}$ series) and macrocyclic lactones (combretastatins D series) have been reported in the literature [21-22]. While the antitumor properties of some of the combrestatins have been reported previously [23-24], their anti-inflammatory effects have also been demonstrated [25-28]. Similar to some other stilbenoids, it appears that one of the mechanisms by which combretastatins exert their antiinflammatory effects might be through attenuating the activation of the NFkB pathway, likely through a reduction of p65 subunit nuclear translocation as demonstrated in DND-41 leukemia and Jurkat T-cell lines [27].

The anti-inflammatory actions of resveratrol and some potential cellular mechanisms have also been reported in in vivo models. Longterm treatment of the fish Nothobranchius guentheri, with resveratrol reversed several senescence-associated secretory activity generally associated with aging in the gut, including down-regulating levels of proinflammatory cytokines IL- 8 and TNF $\alpha$ and up-regulated expression of anti-inflammatory cytokine IL-10 [29]. SenescenceAccelerated Mice (SAM) are commonly used as animal models in aging studies. Ginés $\mathrm{C}$ et al. [30], using SAMP8 mice that are prone to aging, reported an increase in inflammatory status and $\mathrm{NF \kappa B}$ protein expression in the pancreas of the old mice and in addition they reported a decrease in sirtuin 1 and FoxO factors but this was attenuated by administration of resveratrol. Rodríguez-Bies et al. [31], reported that resveratrol improved muscle performance in mature and old animals but not in young mice. In addition, resveratrol also primed the effect of exercise by increasing endurance, coordination and strength in older mice, an effect that was associated with a higher protection against oxidative stress. Similarly, in 16-month old C57BL/6J mice combining resveratrol supplementation with exercise training for 4 weeks increased the muscle strength and endurance performance of aged mice when compared to resveratrol alone [32]. Issuree et al. [33], reported in a mouse model of $\mathrm{C} 5 \mathrm{a}$-induced acute peritonitis that pretreatment with resveratrol significantly attenuated the effects of $\mathrm{C} 5 \mathrm{a}$ on several markers of inflammation including vascular permeability, neutrophil migration as well as release of IL1- $\beta$, TNF- $\alpha$, IL- 6 and MIP- $\alpha$.

The potential anti-inflammatory effects of resveratrol have therapeutic implications in human clinical studies. This is especially relevant for the aging population where chronic low-grade inflammation is a contributing factor to many age-related adverse health conditions. In Peripheral Blood Mononuclear Cells (PBMCs) taken from patients with gout, SIRT1 was down-regulated when exposed to monosodium urate crystals but was restored by resveratrol in a dose-dependent manner with the high doses of resveratrol ameliorating the release of the inflammatory cytokine IL-1 $\beta$ [34]. Osteoarthritis, an aging-related inflammatory condition is characterized by a decrease in SIRT1 in the 
osteoarthritic cartilage and resveratrol can activate SIRT1 to attenuate the progression of osteoarthritis [35]. No effect of resveratrol on inflammation was found in a systematic review and meta-analysis of studies examining the association of two selective established biomarkers of inflammation, IL-6 and C-Reactive Protein (CRP) in middle-age and older adults with chronic low grade inflammation [36]. Rabassa et al. [37], reported that in a longitudinal analysis with data from 769 participants aged $\geq 65 \mathrm{yr}$ from the Invecchiare in Chianti (Aging in Chianti) study, higher habitual dietary resveratrol intake was associated with lower risk developing frailty syndrome during the first $3 \mathrm{y}$ of follow-up but not after longer follow-up periods. The in vitro, in vivo and human studies provide evidence of the anti-inflammatory efficacy of resveratrol and that one of the major intracellular signaling molecules appears to be the SIRT1 (activation of SIRT1) and also attenuation of the NFKB pathway and subsequent decrease in pro-inflammatory cytokines.

\section{Resveratrol and Immune Function in Aging}

The immune system is a key component of inflammation and is body's natural response to injury or infection. Immune function involves several cell types regulating both innate and adaptive responses as well as interactions amongst them while responding to an antigen. Innate immune response is non-specific and relatively immediate whereas adaptive immune response is antigen-specific and delayed. But cells of the innate immune response play an important role in the initiation and subsequent responses of adaptive immune regulation. In addition, proteins of the innate system are crucial in the removal of pathogens following an adaptive immune response. One of the major components of the innate immune system is the activation of the complement proteins. Some of the proteins involved in the complement system are complement Component 3 (C3) and complement Component 5 (C5). Cells of the adaptive immune response include $\mathrm{T}$ and $\mathrm{B}$ lymphocytes and antigen-presenting cells. Natural killer cells (NK cells) may play a role in both innate and adaptive responses and as mentioned above, the functional classification of cell types involved in the activation of the two types of immune responses may not always be distinct.

Immunosenescence is the gradual decline of the immune system with age [38]. While the responses of both the innate and adaptive immune system are attenuated, there is also a decline in the diversity of the antigen repertoire and an accumulation of functionallyimpaired memory lymphocytes that can affect the ability to fight infection or recovery from injury. Resveratrol regulates immune cell function including synthesis of pro-inflammatory cytokines and gene expression, as described above, but its role in combating immunosenescence is less clear and reports are scarce. Yuan et al. [39], reported that dietary intake of resveratrol for 45 days induced a significant increase in CD4+ T-cells in 12 month old and 21 month old Wistar rats. Further, resveratrol supplementation also increased the delayed-type hypersensitivity response, a T-cellmediated immune response, in aged rats. In 24-month-old C57/BL6 aged mice fed control diet or diet supplemented with resveratrol for 8 weeks were challenged with LPS and the acute response of proinflammatory markers assessed in the brain [40]. They reported that an acute LPS injection induced a strong pro-inflammatory response in the hippocampi with an increase in the expression levels of IL6 , TNF- $\alpha$, IL-1 $\beta$ and CXCL10, but resveratrol induced a higher expression of these cytokines in mice already treated with LPS indicating that resveratrol might play an important role in attenuating immunosenescence.
There immune effects of resveratrol on companion animals (dogs and cats) are scarce. But it is conceivable that resveratrol is beneficial in aging by modulating the immune system although the evidence to support this is indirect. For instance, sarcopenia, a generalized decline of skeletal muscle mass and function, affects cats and dogs and aging is an important determinant of sarcopenia [41]. Chronic lowgrade inflammation or systemic inflammation is thought to play an important role in sarcopenia [42]. Pastor et al. [43], recently reported that supplementation of a combination of alpha-tocopherol acetate and resveratrol attenuated the risk of sarcopenia in adult dogs $(5.4+1.4$ $\mathrm{yr}$ old). Whether such a beneficial effect with resveratrol alone or resveratrol in combination with any other ingredient would also show a positive effect in aging dogs is not known but is a possibility and needs to be investigated. Woode et al. [44], collected whole blood from six healthy, adult, client-owned dogs and incubated them with different concentrations of resveratrol for $4 \mathrm{hr}$ with the maximal concentration being $6000 \mathrm{ng} / \mathrm{ml}$. Following incubation, phagocytosis and oxidative burst and cytokine production were evaluated using LPS, Lipoteichoic Acid (LTA), or Peptidoglycan (PG) to stimulate cytokine production. They reported that while phagocytosis was not altered by resveratrol at any concentration compared to control, TNF, IL-6, production was increased and IL-10 levels were decreased with resveratrol. It appears that the acute effects of resveratrol may favor pro-inflammatory effects under some conditions, but whether this has a beneficial effect in some disease states, where an activation of the innate immune response is essential, is not clear but is conceivable. A follow-up study was reported by [45]. They collected whole blood from 12 healthy, adult client-owned dogs on day 0 and 3 of which six dogs received resveratrol, $200 \mathrm{mg} / \mathrm{kg}$, orally once daily for three days and six dogs served as controls. Production of TNF, IL- 6 and IL-10 by leukocytes was analyzed following stimulation by LPS, LTA, or PG. When they measured the cytokines they found that resveratrol had increased TNF and IL-6 levels, however they saw no effect on IL-10. Whether such a difference in the effects of resveratrol in acute versus relatively long exposure is due to the underlying pharmacokinetics of resveratrol in dogs is not clear. Muzzio et al. [46], reported that in dogs after a 13 week oral administration of resveratrol in 40 healthy beagle dogs, the peak resveratrol plasma concentration in dogs ranged between 1-5h after oral dosing and that resveratrol was rapidly metabolized to glucuronide and sulfate. Interestingly, cats appear to have low activity of $\beta$-glucuronidase and [47], reported that resveratrol metabolites, resveratrol-3-O-glucuronide and resveratrol4'-O-glucuronide could not be detected in the blood or urine of intact male and female cats given resveratrol orally for 4 weeks at $3 \mathrm{mg} /$ cat/day, although resveratrol-3-O-sulphate was significantly higher in resveratrol-fed cats when compared to controls. Glucuronidation, or lack thereof, can initiate an immune response $[48,49]$. The beneficial effects of resveratrol or other stilbenoids in cats are scarce although resveratrol has been reported to have protective effects in cats against arsenic trioxide-induced oxidative stress in feline and lungs [50] and brain [51]. Given the protective effects of resveratrol, the immunemodulating effects of resveratrol or other stilbenoids in cats and dogs is a promising area of research, especially its effects on the aging immune system.

Kaszubowska et al [52], reported that in a study involving older subjects age $>$ over $85 \mathrm{yr}$ ), old subjects (age $<85 \mathrm{yr}$ ) and young sub.jects (mean age $21 \pm 0.3 \mathrm{yr}$ ), the oldest subjects had a much higher percentage of both NKT-like cells and T-lymphocytes expressing SIRT1, HSP70 and SOD2. NKT-like cells are CD1d-independent NKT cells are a 
subset of T-cells which represent highly differentiated, conventional T lymphocytes co-expressing several NK (Natural Killer) associated receptors. While the study by Kaszubowska et al. [52], did not assess the role of resveratrol, given that resveratrol can activate SIRT1, it is conceivable that resveratrol can modulate NKT-cells and thus play a role in immunosenescence. Interestingly, Owczarz et al. [53], reported that in PBMCs from young (mean age $27 \pm 4.3 \mathrm{yr}$ ), elderly $(65 \pm 3.4 \mathrm{yr})$ and long-lived $(94 \pm 3.5 \mathrm{yr})$ individuals, there was an agerelated decrease of SIRT1 expression in PBMCs. Since PBMCs are composed of T-cells, B-Cells, NK cells and monocytes and so it is not clear if the decline in SIRT1 seen in elderly is indicative of a general decline in SIRT1 in all cell types and assessing SIRT1 in individual cell types might have provided a clearer picture on the levels of SIRT1 in aging in leukocytes. Regardless, from these studies it is evident that the immunostimulatory properties of resveratrol in aging needs to be investigated further and these studies provide a strong rationale that resveratrol has the potential to modulate the humoral and cellmediated immune responses in aging.

\section{Resveratrol and Renal Function in Aging}

There is evidence to indicate that changes in renal structure (reduction in mass) and function Glomerular Filtration Rate (GFR) accompany aging [54-56]. While the number of tubular cells and glomerular cells decreases significantly with aging in humans, the number of glomerular tufts per unit area may also decrease significantly with advancing age [57]. Several associated functional changes take place with aging, including a decline in renal blood flow and sodium clearance and the ability to maximally concentrate urine. Such reduction in renal function with aging is likely multi-factorial [58], but an increase in inflammatory processes is hypothesized to play an important role in the decline of renal function [59-60].

Resveratrol may be one option to consider in improving kidney function in aging (see [61] for review) although as mentioned later more studies are warranted to determine the efficacy of resveratrol in aging. Studies from in vitro and in vivo studies indicate that resveratrol may play a protective role in kidney function. Abharzanjani et al. [62], reported that human embryonic kidney cells (HEK-293 cells) when treated with high glucose to simulate hyperglycemic conditions, decreased levels of thioredoxin, an antioxidant protein, but this decline was attenuated in the presence of increasing doses of resveratrol. Using both in vitro and in vivo studies Hsu et al. [63], demonstrated that in the mouse kidney resveratrol significantly increased both Klotho mRNA and protein expression and Klotho was also up-regulated in resveratrol-treated NRK-52E cells. Klotho functions as an aging suppressor gene [64] and a decrease in Klotho gene expression is also reported in chronic kidney failure patients [65]. The Renin-Angiotensin System (RAS) may play a diverse role in renal aging function. Angiotensin II (Ang II)/ Angiotensin II Type 1 Receptor (AT1R) axis may increase tissue ROS production whereas the angiotensin 1-7 (Ang 1-7)/ Mas Receptor (MasR) axis may play a protective role. In C57BL/6 mice fed resveratrol for 6 months, resveratrol suppressed the Ang II/AT1R axis and enhanced the AT2R/ Ang 1-7/MasR axis when compared to controls [66] and a reduction in inflammation is hypothesized to be one of the mechanisms of the protective effect. Ryu et al. [67], reported that kidneys from aged mice showed increased infiltration of CD68-positive macrophages as well as higher expression of Extracellular Matrix (ECM) proteins, when compared to young controls and this was associated with decreased
SIRT1 levels. However, resveratrol significantly attenuated hypoxiainduced production of ECM proteins, mitochondrial damage, reactive oxygen species generation and apoptosis and thus may play a role in protection against tubulointerstitial damage in aged kidney. Resveratrol can also regulate the nuclear factor (erythroid-derived 2)like 2 (Nrf2) protein, a transcription factor that increases expression of antioxidant enzymes in the cell and also regulates inflammation and senescence [68]. Resveratrol when administered to 18-month aged mice for 6 months improved renal function, proteinuria, as well histological changes and inflammation in aging mice and this was hypothesized to be mediated through up-regulating Nrf2 and SIRT1 signaling pathways [69]. In Streptozotocin (STZ)-induced diabetic rats which also develop diabetic nephropathy, hyperglycemia significantly enhanced production of pro-inflammatory cytokine IL$1 \beta$ in the kidney but resveratrol reduced IL-1 $\beta$ although it increased the pro-inflammatory TNF- $\alpha$ and IL- 6 levels in the diabetic kidneys [70]. Long-term studies with resveratrol to study its effects on renal function in aging are lacking. However, Wong et al. [71], reported that while 6-month treatment of resveratrol in drinking water to F2 hybrid mice reduced protein carbonylation, a marker of oxidative stress, in the liver and kidney, the 12-month treatment resulted in a significant elevation of protein carbonylation, a marker of oxidative damage and 8-iso-PGF-2 $\alpha$, marker of DNA damage, in the kidney. This study provides a rationale for long-term studies with resveratrol indicates to assess whether it might exacerbate the oxidative stress effects of aging on kidney function. Liu et al. [72], demonstrated that in mice with unilateral ureteral obstruction, low-dose of resveratrol partly improved renal function, whereas the higher dose aggravated renal fibrosis. Saldanha et al. [73], reported in a pilot study that 500 $\mathrm{mg}$ of resveratrol supplementation for 4 weeks had no antioxidant and anti-inflammatory effect in 20 non-dialyzed patients with chronic kidney disease. While several above-mentioned studies in vitro and in vivo conditions appear to support the notion that resveratrol may have beneficial effects in renal function, human studies are scarce to indicate any benefit of resveratrol in kidney function. In addition, reports on the effects of resveratrol on improving kidney function in aging are negligible and thus warrant conducting robust animal and human studies.

\section{Resveratrol and Cognitive Function in Aging}

The association between systemic inflammation and cognitive deficits has been documented. Several inflammatory markers are elevated in the serum including levels of pro-inflammatory cytokines IL- $6, \mathrm{TNF}-\alpha$ and CRP. These inflammatory proteins are associated with an impairment in specific components of cognitive function in human studies [74-76]. In a longitudinal study using two subsamples of aging adults $(n=9066$ and $n=12,561)$ from the English Longitudinal Study of Ageing (ELSA) study, greater body mass was indirectly associated with a decline in memory function over $6 \mathrm{yr}$ and this was associated with relatively higher levels of circulating CRP [77]. Trollor et al. [78], also reported increased markers of systemic inflammation including IL-12 and IL-6 in 873 non-demented community-dwelling elderly participants aged 70-90 $\mathrm{yr}$ and this was related cognitive deficits. In addition to the increases in circulating levels of the generally accepted pro-inflammatory markers, as mentioned above, several other immune markers have also been implicated in cognitive decline in aging. Bettcher et al. [79], reported that in a sample of 399 asymptomatic older adults (mean age $=72.1 \mathrm{yr}$ ), when assessed longitudinally for changes in memory function using a test for longitudinal verbal memory measure. 
Citation: Tavener SK, Panickar KS (2020) Anti-Inflammatory Effects of Resveratrol and Related Polyphenols Contribute to their Potential Beneficial Effects in Aging. J Food Sci Nutr 6: 079.

They report an increase in the within-subject serum levels of Monocyte Chemoattractant Protein-1 (MCP-1) and this was associated with a decrease in delayed recall, a component of cognitive function. Similarly, in a population-based sample of 215 working adults (25-67 yr), MCP-1 was found to be elevated and this was associated with poorer executive cognitive functioning [80]. These studies indicate an important role of pro-inflammatory proteins in attenuating cognitive function and strategies to reduce such inflammation through diet and nutrition or supplements including polyphenols are desirable (Table $1)$.

\begin{tabular}{|c|c|c|c|c|}
\hline Study Design & $\begin{array}{c}\text { Resveratrol Dose and Adminis- } \\
\text { tration }\end{array}$ & $\begin{array}{l}\text { Results for Cognition or Learning and } \\
\text { Memory }\end{array}$ & Potential Anti-Inflammatory Mechanism & References \\
\hline $\begin{array}{l}\text { High-fat diet induced cognitive } \\
\text { dysfunction in } 22 \text { month aged C56/ } \\
\text { BL6 mice. }\end{array}$ & $\begin{array}{l}\text { Standard chow diet enriched with } \\
\text { resveratrol }(1 \mathrm{~g} / \mathrm{kg}, \mathrm{w} / \mathrm{w}) \text { providing } \\
\text { approximately } 160 \mathrm{mg} / \mathrm{kg} \text { resvera- } \\
\text { trol daily intake for } 8 \mathrm{wk} \text {. }\end{array}$ & $\begin{array}{l}\text { No significant improvement was seen in } \\
\text { old mice fed resveratrol when compared } \\
\text { to age-matched controls as assessed using } \\
\text { Morris water maze (MWM). } \\
\text { In the high-fat + resveratrol fed aged mice } \\
\text { there was an improvement in the Novel } \\
\text { Object Recognition Task when compared } \\
\text { to aged high-fat fed controls. }\end{array}$ & $\begin{array}{l}\text { Resveratrol generally increased mRNA of inflam- } \\
\text { matory markers TNF-a, CXCL10, IL-1, IL- } 6 \text { and } \\
\text { CCL-3 in the hippocampus of aged+resveratrol } \\
\text { group when compared to aged matched controls. } \\
\text { In the high-fat + resveratrol fed aged mice there } \\
\text { was a modest decrease in these inflammatory } \\
\text { markers induced by high-fat diet }\end{array}$ & [81] \\
\hline $\begin{array}{l}\text { Effects of resveratrol on oxidative } \\
\text { damage and cognition in 3-month } \\
\text { old senescence-accelerated mice } \\
\text { (SAM) }(\mathrm{n}=50)\end{array}$ & $\begin{array}{l}\text { Resveratrol dissolved in } 0.1 \% \\
\text { CMC and given by intra-gastric } \\
\text { gavage at doses of } 25,50 \text { and } \\
100 \mathrm{mg} / \mathrm{kg} \text { daily for } 8 \text { wks. } \\
\text { Resveratrol treated groups had } \\
\text { improved learning and memory } \\
\text { with Morris water maze test when } \\
\text { compared to other groups. }\end{array}$ & $\begin{array}{l}\text { Resveratrol groups also had improved neu- } \\
\text { romuscular coordination and sensorimotor } \\
\text { capacity when compared to normal and } \\
\text { model groups. }\end{array}$ & $\begin{array}{l}\text { Superoxide Dismutase (SOD) - This antioxidant } \\
\text { enzyme that scavenges superoxide radicals, had } \\
\text { increased levels of activity in all } 3 \text { groups of } \\
\text { resveratrol when compared to model group. SOD } \\
\text { also has an anti-inflammatory effect. }\end{array}$ & [82] \\
\hline $\begin{array}{l}\text { Four groups of } 3 \text {-month old Wistar } \\
\text { rats. }(n=16 \text { in each period was } n=16 \text {, } \\
\text { except at month } 8 \text { where } n=32)\end{array}$ & $\begin{array}{l}\text { Resveratrol }(10 \mathrm{mg} / \mathrm{kg} / \text { day }) \text { or } \\
\text { Vitamin } \mathrm{E}(2 \mathrm{mg} / \mathrm{kg} / \mathrm{day}) \text {, adminis- } \\
\text { tered at } 2,4,6, \& 8 \text { months. }\end{array}$ & $\begin{array}{l}\text { Behavioral tests using Novel Object } \\
\text { Recognition (NOR) task performed on } \\
\text { the group administered resveratrol for } \\
8 \text { months. Recognition index for NOR } \\
\text { showed a } 20 \% \text { increase in long term mem- } \\
\text { ory when compared to the control group }\end{array}$ & $\begin{array}{l}\text { Chronic resveratrol treatment preserves cerebral } \\
\text { integrity in CA1 and CA2 region of hippocampus } \\
\text { and enhances cognitive performance in long term } \\
\text { memory. Whether the anti-inflammatory and } \\
\text { antioxidant effects of resveratrol played a role in } \\
\text { preserving cerebral integrity and thus improving } \\
\text { memory is not clear but a possibility. }\end{array}$ & [83] \\
\hline $\begin{array}{l}\text { Wistar rats ( } \mathrm{n}=8 \text { in placebo group } \\
\text { and in the resveratrol group). }\end{array}$ & $\begin{array}{l}\text { Resveratrol } 10 \mathrm{mg} / \mathrm{kg} \text { given p.o. } \\
\text { for } 4 \text { weeks }\end{array}$ & $\begin{array}{l}\text { ELSIA was performed to measure BDNF } \\
\text { levels after } 0,2 \text { and } 4 \text { weeks of treatment. } \\
\text { Serum BDNF concentration levels signifi- } \\
\text { cantly increased at } 2 \text { weeks and } 4 \text { weeks, } \\
\text { although the } 4 \text { week resveratrol group } \\
\text { difference was not significant to } 2 \text { week } \\
\text { resveratrol group. } \\
\text { Resveratrol-treated group with L-NAME } \\
\text { (inhibitor of NOS-3, where NOS-3 } \\
\text { contributes to vasorelaxation) significant- } \\
\text { ly reduced PHE-induced contraction of } \\
\text { VSMC when compared to control group } \\
\text { with L-NAME }\end{array}$ & $\begin{array}{l}\text { BDNF may have played a neurotrophic role in and } \\
\text { thus may have contributed to improved cognition } \\
\text { in the resveratrol group. BDNF has been reported } \\
\text { to have anti-inflammatory effects. } \\
\text { Further, the ability of resveratrol to reduce VSMC } \\
\text { contractility may enhance neuroprotection and aid } \\
\text { in the prevention of cognitive impairment. }\end{array}$ & {$[84,85]$} \\
\hline Adult male Wistar rats $(\mathrm{n}=50)$ & $\begin{array}{l}\text { Resveratrol } 5 \mathrm{mg} / \mathrm{kg} / \text { day or } 20 \mathrm{mg} / \\
\mathrm{kg} / \text { day for } 35 \text { days. }\end{array}$ & $\begin{array}{l}\text { When compared to control groups using } \\
\text { Morris water maze, passive avoidance and } \\
\text { locomotor activity tests. } \\
\text { CUMS rats treated with resveratrol at } 5 \mathrm{mg} / \\
\text { kg scored poorly in Morris water maze and } \\
\text { passive avoidance tests. }\end{array}$ & $\begin{array}{l}\text { Resveratrol may have the ability to increase } \\
\text { levels of BDNF and c-Fos expression and lower } \\
\text { plasma levels of TNF- } \alpha \text { and IL- } 1 \beta \text {, reversing the } \\
\text { negative effects of chronic stress, while improving } \\
\text { cognition. } \\
\text { CUMS rats treated with resveratrol at } 20 \mathrm{mg} / \mathrm{kg} \\
\text { reversed the effects of lower BDNF and c-Fos } \\
\text { expression in CA1 and CA } 3 \text { region of hippocam- } \\
\text { pus, as well as in the amygdala that were caused } \\
\text { by chronic stress. Increased TNF- } \alpha \text { and IL- } 1 \beta \\
\text { levels due to stress were reduced with } 20 \mathrm{mg} / \mathrm{kg} \\
\text { resveratrol. }\end{array}$ & [86] \\
\hline $\begin{array}{l}\text { Four groups of Wistar rats, aged } \\
12-14 \text { months; } n=20 / \text { Group. } \\
\text { Group A-Control group-sham } \\
\text { surgery; Group B-VaD modeling } \\
\text { surgery;, Group C-Control + } \\
\text { resveratrol; Group D-VaD modeling } \\
\quad \text { surgery + resveratrol. }\end{array}$ & $\begin{array}{c}\text { Groups } C \text { and D received daily } \\
\text { oral dose resveratrol at } 25 \mathrm{mg} / \mathrm{kg} \text {, } \\
8 \text { weeks post-surgery until } 12 \text { after } \\
\text { surgery. }\end{array}$ & $\begin{array}{l}\text { Morris water maze test was used to } \\
\text { measure spatial learning and memory } \\
\text { performance. The resveratrol treatment } \\
\text { group showed significantly shorter escape } \\
\text { latency and escape distance compared to } \\
\text { rats in model group. }\end{array}$ & $\begin{array}{c}\text { Levels for Bax, caspase-3, cleaved PARP } \\
\text { (pro-apoptotic) were significantly reduced, but } \\
\text { levels for Bcl-2 (anti-apoptotic) were significantly } \\
\text { increased and Bax/Bcl-2 ratio was also decreased } \\
\text { in resveratrol group compared to controls } \\
\text { While levels of inflammatory markers were not } \\
\text { assessed, it is conceivable that a reduction of in } \\
\text { some of the pro-apoptotic molecules played a role } \\
\text { in reduced inflammation. }\end{array}$ & [87] \\
\hline
\end{tabular}


Citation: Tavener SK, Panickar KS (2020) Anti-Inflammatory Effects of Resveratrol and Related Polyphenols Contribute to their Potential Beneficial Effects in Aging. J Food Sci Nutr 6: 079.

\begin{tabular}{|c|c|c|c|c|}
\hline $\begin{array}{l}\text { Wistar rats- Young ( } 3 \text { months, } n=8) \\
\text { and old ( } 20 \text { months, } n=14)\end{array}$ & $\begin{array}{c}\text { Young }(\mathrm{n}=8) \text {; vehicle control } \\
\text { (corn oil } 1 \mathrm{mg} / \mathrm{kg} \text { i.p.) for } 30 \text { days. } \\
\text { Old }(\mathrm{n}=8) \text { Vehicle control } \\
\text { Old ( } \mathrm{n}=6) \text {-resveratrol }(20 \mathrm{mg} / \mathrm{kg} \\
\text { per day). }\end{array}$ & $\begin{array}{l}\text { Radial maze test was used for working } \\
\text { memory and rats treated with resveratrol } \\
\text { showed reduced time and reduced number } \\
\text { of errors when compared to control group. }\end{array}$ & $\begin{array}{c}\text { Tryptophan Hydroxylase } 1 \text { (TPH-1), TPH-2 and } \\
\text { Tyrosine Hydroxylase (TH) had increased activity } \\
\text { in resveratrol group. TPH-1 deficiency can induce } \\
\text { neuroinflammation. }\end{array}$ & {$[88,89]$} \\
\hline $\begin{array}{c}\text { Four groups of Wistar Kyoto } \\
\text { (WKY) rats, aged } 10 \text { weeks; } \mathrm{n}=4 / \\
\text { Group: (Group A) sham group, } \\
\text { (Group B) WKY + Ang-II, (Group } \\
\text { C) WKY + Ang-II + losartan, } \\
\text { (Group D) WKY + Ang-II + } \\
\text { resveratrol }\end{array}$ & $\begin{array}{l}\text { All groups were treated for } 14 \\
\text { days. Resveratrol was adminis- } \\
\text { tered at } 10 \mathrm{mg} / \mathrm{kg} / \text { day. }\end{array}$ & $\begin{array}{l}\text { Both resveratrol and losartan treated } \\
\text { groups showed lower systolic blood pres- } \\
\text { sure, lower superoxide levels in the NTS } \\
\text { and increased BDNF levels. }\end{array}$ & $\begin{array}{l}\text { Contextual memory possibly improved by the } \\
\text { deletion of NADPH oxidase } 2 \text { and elevation of } \\
\text { superoxide dismutase } 2 . \\
\text { Resveratrol may reduce oxidative stress and } \\
\text { increase BDNF levels in order to prevent memory } \\
\text { impairment. } \\
\text { Resveratrol and losartan improved hippocam- } \\
\text { pal-dependent and impaired contextual memory }\end{array}$ & [90] \\
\hline $\begin{array}{l}\text { C57BL/6 mice (8-month old) were } \\
\text { injected with scopolamine ( } 1.5 \mathrm{mg} / \\
\mathrm{kg}) 30 \text {-min prior to the behavioral } \\
\text { test to induce cognitive deficits. }\end{array}$ & $\begin{array}{l}\text { Treated with resveratrol oligomers } \\
\text { from the seed coat extract of } \\
\text { Paeonia Suffruticosa (PSCE), at } \\
\text { doses of } 150 \text { and } 600 \mathrm{mg} / \mathrm{kg} \text { for } \\
28 \text { days. }\end{array}$ & $\begin{array}{l}\text { PSCE improved the cognitive performance } \\
\text { of scopolamine-treated mice in behavioural } \\
\text { tests including novel object recognition } \\
\text { test, Morris water maze and inhibitor } \\
\text { avoidance task. }\end{array}$ & $\begin{array}{l}\text { PSCE }(150 \mathrm{mg}) \text {, but not } 600 \mathrm{mg} \text {, significantly } \\
\text { reduced scopolamine-induced increase in serum } \\
\text { IL-1 } \beta \text {, IL- } 6 \text { and TNF- } \alpha \text {. Scopolamine-induced } \\
\text { decreased IL- } 4 \text { levels were increased by both } \\
\text { doses of resveratrol. }\end{array}$ & [91] \\
\hline $\begin{array}{l}\text { Senescence Accelerated Mouse- } \\
\text { Prone (SAMP8), a non-transgenic } \\
\text { mice strain, mothers were fed } \\
\text { resveratrol }(1 \mathrm{~g} / \mathrm{Kg}) \text { for two months. }\end{array}$ & $\begin{array}{l}\text { Two generations of offspring were } \\
\text { fed a standard diet and were tested } \\
\text { for cognitive performance with } \\
\text { the offspring of SAMP8 that were } \\
\text { fed standard chow. }\end{array}$ & $\begin{array}{l}\text { Both generations of offspring from } \\
\text { resveratrol-fed mothers demonstrated im- } \\
\text { provements in cognition Object novel rec- } \\
\text { ognition and Morris Water Maze (MWM) } \\
\text { tests when compared to controls. }\end{array}$ & $\begin{array}{l}\text { Methylation levels of the promoter region of the } \\
\text { transcription factor gene NF-kb was increased in } \\
\text { resveratrol-fed offspring mice brain hippocampus } \\
\text { and a reduction in IL-6 and CXCL10 was also } \\
\text { observed when compared to controls. }\end{array}$ & [92] \\
\hline $\begin{array}{l}\text { Double-blind study involving } 46 \\
\text { healthy older }(50-80 \mathrm{yr}) \text { and over- } \\
\text { weight }(\mathrm{BMI}=25-30 \mathrm{~kg} / \mathrm{m} 2) \text { adults. }\end{array}$ & $\begin{array}{l}\text { Received either placebo or } 200 \mathrm{mg} \\
\text { resveratrol }+320 \mathrm{mg} \text { quercetin for } \\
26 \text { weeks. }\end{array}$ & $\begin{array}{l}\text { Resveratrol group had a significant } \\
\text { increase in retention of words over } 30 \\
\text { minutes. }\end{array}$ & $\begin{array}{l}\text { There was a reduction in inflammatory markers } \\
\text { TNF- } \alpha \text { and IL- } 6 \text { but in both placebo and resvera- } \\
\text { trol groups, when pre-treatment was compared to } \\
\text { post. No statistically significant changes in hsCRP } \\
\text { or BDNF levels were reported. }\end{array}$ & [93] \\
\hline $\begin{array}{l}\text { A } 14 \text { week double-blind, random- } \\
\text { ized trial involving post-menopausal } \\
\text { women } 45-85 \text { yrs. old }(n=80) \text {. }\end{array}$ & $\begin{array}{c}\text { Received either } 75 \mathrm{mg} \text { of } 99 \% \\
\text { pure synthetic trans-resveratrol } \\
\text { (ResVidaTM) twice/day or place- } \\
\text { bo for } 14 \text { weeks. }\end{array}$ & $\begin{array}{l}\text { Significant improvement in resveratrol } \\
\text { group for verbal memory and overall } \\
\text { cognitive performance. } \\
\text { The Category fluency and Camel and Cac- } \\
\text { tus both showed an increase in CVR. }\end{array}$ & $\begin{array}{l}\text { Resveratrol significantly improved CVR and this } \\
\text { may be due to its ability to regulate cerebral blood } \\
\text { flow. An increase in CVR showed an interconnec- } \\
\text { tion with improved verbal memory and cognitive } \\
\text { performance. }\end{array}$ & [95] \\
\hline $\begin{array}{c}\text { A double-blind, randomized } \\
\text { controlled trial in } 60 \text { healthy elderly } \\
\text { subjects }(60-79 \mathrm{yr}) . \text { Range of BMI }= \\
21-37 \mathrm{~kg} / \mathrm{m} 2 .\end{array}$ & $\begin{array}{l}\text { Received either resveratrol } \\
(200 \mathrm{mg} / \text { day })+\text { quercetin }(320 \mathrm{mg} / \\
\text { day) or placebo for } 26 \mathrm{wks} \text {. }\end{array}$ & $\begin{array}{l}\text { No significant enhancement in memory } \\
\text { performance in resveratrol group after } 6 \\
\text { months compared to controls when as- } \\
\text { sessed in California Verbal Learning Task } \\
\text { (CVLT, main outcome). Non-significant } \\
\text { improvement in the ModBent task (an ob- } \\
\text { ject recognition task) in resveratrol group. }\end{array}$ & $\begin{array}{l}\text { Overall increases in serum hsCRP, IL- } 6 \text { and } \\
\text { TNF- } \alpha \text { in both control and resveratrol groups. } \\
\text { HbAlc levels also did not change when compared } \\
\text { to placebo group. }\end{array}$ & [96] \\
\hline \multicolumn{5}{|l|}{ Abbreviations: } \\
\hline \multicolumn{5}{|c|}{$\begin{array}{l}\text { ADAS-Cog: Alzheimer's Disease Assessment Scale-cognitive; ADCS-ADL: Alzheimer's Disease Cooperative Study-Activities of Daily Living Scale; AVLT: Auditory verbal } \\
\text { learning test; BDNF: Brain-derived neurotrophic factor; BMI: Body mass index; CBF: cerebral blood flow; CCL3: Chemokine (C-C motif) ligand 3; CDR-SOB: Clinical dementia } \\
\text { rating-sum of boxes; CMC: Carboxymethyl cellulose sodium; CUMS: Chronic unpredictable mild stress; CVLT: California verbal learning task; CVR: Cerebrovascular respon- } \\
\text { siveness; FC: Functional connectivity; GSH-Px: Glutathione peroxidase; HbAlc: Glycated hemoglobin; MDA: Malondialdehyde; MMSE: Mini-mental state examination; NOR } \\
\text { Novel objects recognition; NPI: Neuropsychiatric inventory; NTS: Nucleus tractus solitarius; PARP: Poly (ADP-ribose) polymerase; PHE: Phenylephrine; POMS: Profile of mood } \\
\text { status; SAM: Senescence-accelerated mouse; SOD: Superoxide dismutase; TH: Tyrosine hydroxylase; TPH: Tryptophan hydroxylase; TrkB: Tyrosine kinase receptor B; VaD } \\
\text { Vascular dementia; VSMC: Vascular smooth muscle cells. }\end{array}$} \\
\hline
\end{tabular}

The above table summarizes the outcome of several studies regarding the anti-inflammatory effects of resveratrol and the potential for improved cognition in both rodents and humans. Results from most of the rodent studies provided similar findings, i.e. an improvement in memory. At the cellular and molecular level resveratrol appears to increase BDNF, a neurotrophin, which binds to TrkB receptor which causes an increase in plasticity in the brain and is involved with many processes which improve cognition [85]. Multiple studies in this table have shown that BDNF levels have increased in resveratrol treatment groups. The anti-inflammatory effects of BDNF have also been documented [84]. Along with increasing levels of BDNF, resveratrol was shown to also increase c-Fos protein 
Citation: Tavener SK, Panickar KS (2020) Anti-Inflammatory Effects of Resveratrol and Related Polyphenols Contribute to their Potential Beneficial Effects in Aging. J Food Sci Nutr 6: 079.

expression, while lowering plasma levels of TNF- $\alpha$ and IL-1 $\beta$ in rats exposed to CUMS, which may aid in reducing the negative effects of chronic stress, while improving cognition [86]. Another study measured levels for Bax and Bcl-2 (genes responsible for regulating apoptotic cell death) and it was found that levels for Bcl-2 were significantly increased, Bax were significantly reduced and the Bax/ Bcl-2 ratio was significantly decreased in the resveratrol treatment group. Cleaved caspace-3 and PARP were significantly reduced as well, providing a possible neuroprotective effect of resveratrol [87]. Whether a reduction in apoptotic cells may have resulted in reduced inflammation is not clear from some of the studies cited in the table, although reduced clearance of apoptotic cells may lead to prolonged inflammation [97]. It is therefore conceivable that the effects of resveratrol, by reducing apoptotic markers, may have indirectly played a role in its anti-inflammatory effects and subsequent improvement in cognition. In human studies the effects of resveratrol in improving cognition are less consistent although a trend towards an overall improvement in cognitive function. For instance, one metaanalysis that reported results obtained from 226 individuals from four randomized clinical trials evaluating the effects of resveratrol on cognition did not support the role for resveratrol in improving cognition [98]. It should, however, be noted that there are limitations in meta-analysis studies and often times it is not possible to include certain studies in meta-analysis for various reasons. Regardless, metaanalysis do provide a succinct analysis which can be investigated further. In the current review circulating levels of inflammatory markers were not assessed in most reported human studies making the association between inflammation and cognition in human studies difficult to assess. Nonetheless, the anti-inflammatory effects of resveratrol, directly or indirectly, may have the potential to improve cognitive functions although more studies are warranted.

\section{Conclusion/Perspectives}

There is evidence to indicate from rodent or non-human studies that resveratrol has the potential to exert anti-inflammatory effects and thus have beneficial health effects in aging. Some of the molecular actions of resveratrol, even when not assessed in aging studies, are relevant to aging and thus their potential to have a benefit in aging can be extrapolated. This would be particularly relevant when assessing the actions of various immune molecules including pro-inflammatory cytokines or chemokines. Surprisingly, not many studies have assessed the effects of resveratrol in renal function in aging and more studies would certainly benefit from rodent or well-controlled human studies with kidney dysfunction. Further, well-conducted human trials are limited when assessing the effects of systemic inflammation and cognition. Resveratrol appears to have benefits when given to companion animals but more research is warranted and the acute and long-term effects of resveratrol need to be investigated thoroughly especially on the aging immune system. At the cellular level, while more intracellular mechanisms of resveratrol are being elucidated, the precise mode of resveratrol's anti-inflammatory actions is not clear. Blockade of NFKB signaling pathway and activation of SIRT1 and SIRT1-mediated signaling pathways appear to play an important role in the anti-inflammatory effects of resveratrol. Regardless of whether resveratrol is developed further for subsequent human studies, understanding some of the resveratrol-mediated intracellular signaling pathways, important in health in aging, will hopefully lead to development of newer and more efficacious therapeutics.

\section{Conflict of Interest}

Both authors (SKT, KSP) are employees of Hills pet Nutrition Inc, a Colgate-Palmolive owned company.

\section{References}

1. De Sá Coutinho D, Pacheco MT, Frozza RL, Bernardi A (2018) Anti-inflammatory effects of resveratrol: Mechanistic insights. Int J Mol Sci 19: 1812 .

2. Li QS, Li Y, Deora GS, Ruan BF (2019) Derivatives and analogues of resveratrol: Recent advances in structural modification. Mini Rev Med Chem 19: 809-825.

3. Csiszar A (2011) Anti-inflammatory effects of resveratrol: Possible role in prevention of age-related cardiovascular disease. Ann N Y Acad Sci 1215: 117-122.

4. Akinwumi BC, Bordun KM anderson HD (2018) Biological activities of stilbenoids. Int J Mol Sci 19: 792

5. Pannu N, Bhatnagar A (2019) Resveratrol: From enhanced biosynthesis and bioavailability to multitargeting chronic diseases. Biomed Pharmacother 109: 2237-2251.

6. Nayagam VM, Wang X, Tan YC, Poulsen A, Goh KC, et al. (2006) SIRT1 modulating compounds from high-throughput screening as anti-inflammatory and insulin-sensitizing agents. J Biomol Screen 8: 959-967.

7. Knobloch J, Wahl C, Feldmann M, Jungck D, Strauch J, et al. (2014) Resveratrol attenuates the release of inflammatory cytokines from human bronchial smooth muscle cells exposed to lipoteichoic acid in chronic obstructive pulmonary disease. Basic Clin Pharmacol Toxicol 114: 202-209.

8. Park GJ, Kim YS, Kang KL, Bae SJ, Baek HS, et al. (2013) Effects of sirtuin 1 activation on nicotine and lipopolysaccharide-induced cytotoxicity and inflammatory cytokine production in human gingival fibroblasts. Journal Periodontal Res 48: 483-492.

9. Steiner N, Balez R, Karunaweera N, Lind JM, Münch G, et al. (2016) Neuroprotection of Neuro2a cells and the cytokine suppressive and anti-inflammatory mode of action of resveratrol in activated RAW264.7 macrophages and C8-B4 microglia. Neurochem Int 95: 46-54.

10. Kimbrough CW, Lakshmanan J, Matheson PJ, Woeste M, Gentile A, et al. (2015) Resveratrol decreases nitric oxide production by hepatocytes during inflammation. Surgery 158: 1095-1101.

11. Wakabayashi I, Takeda Y (2013) Inhibitory effects of resveratrol on MCP1, IL-6 and IL-8 production in human coronary artery smooth muscle cells. Naunyn Schmiedebergs Arch Pharmacol 386: 835-839.

12. Lee JH, Song MY, Song EK, Kim EK, Moon WS, et al. (2009) Over expression of SIRT1 protects pancreatic beta-cells against cytokine toxicity by suppressing the nuclear factor-kappaB signaling pathway. Diabetes 58 : 344-351.

13. Liu CW, Sung HC, Lin SR, Wu CW, Lee CW, et al. (2017) Resveratrol attenuates ICAM-1 expression and monocyte adhesiveness to TNF- $\alpha$-treated endothelial cells: Evidence for an anti-inflammatory cascade mediated by the miR-221/222/AMPK/p38/NF- $\mathrm{B}$ pathway. Sci Rep 7: 44689.

14. Subedi L, Baek SH, Kim SY (2018) Genetically engineered resveratrol-enriched rice inhibits neuroinflammation in lipopolysaccharide-activated BV2 microglia via downregulating mitogen-activated protein kinase-nuclear factor kappa B signaling pathway. Oxidative Medicine and Cellular Longevity 2018: 1-15.

15. Yoshizaki T, Milne JC, Imamura T, Schenk S, Sonoda N, et al. (2009) SIRT1 exerts anti-inflammatory effects and improves insulin sensitivity in adipocytes. Mol Cell Biol 29: 1363-1374. 
Citation: Tavener SK, Panickar KS (2020) Anti-Inflammatory Effects of Resveratrol and Related Polyphenols Contribute to their Potential Beneficial Effects in Aging. J Food Sci Nutr 6: 079.

16. Hankittichai P, Buacheen P, Pitchakarn P, Na Takuathung M, Wikan N, et al. (2020) Artocarpus lakoocha extract inhibits LPS-induced inflammatory response in raw 264.7 macrophage cells. Int J Mol Sci 21: 1355.

17. Ashikawa K, Majumdar S, Banerjee S, Bharti AC, Shishodia S, et al (2002) Piceatannol inhibits TNF-induced NF-kappaB activation and NF-kappaB-mediated gene expression through suppression of IkappaBalpha kinase and p65 phosphorylation. J Immunol 169: 6490-6497.

18. Piotrowska H, Kucinska M, Murias M (2012) Biological activity of piceatannol: Leaving the shadow of resveratrol. Mutat Res 750: 60-82.

19. Zhu T, Fang F, Sun D, Yang S, Zhang X, et al. (2020) Piceatannol inhibit $\mathrm{P}$. acnes-induced keratinocyte proliferation and migration by downregulating oxidative stress and the inflammatory response. Inflammation 43 . 347-357.

20. Dvorakova M, Landa P (2017) Anti-inflammatory activity of natural stilbenoids: A review. Pharmacol Res 124: 126-145.

21. Pettit G, Cragg G, Herald D, Schmidt J, Lohavanjijaya P (1982) Isolation and structure of combretastatin. Canadian Journal of Chemistry 60: 1374 1376 .

22. Pettit G, Singh S, Niven M, Hamel E, Schmidt J (1987) Isolation, structure and synthesis of combretastatins A-1 and B-1, potent new inhibitors of microtubule assembly, derived from Combretum caffrum. J Nat Prod 50: 191-231.

23. Pettit GR, Singh SB, Niven ML (1988) Antineoplastic agents. 160. Isolation and structure of combretastatin D-1: A cell growth inhibitory macrocyclic lactone from Combretum caffrum. Journal of the American Chemical Society 110: 8539-8540.

24. Pettit GR, Singh SB, Boyd MR, Hamel E, Pettit RK, et al. (1995) Antineoplastic Agents. 291. Isolation and synthesis of combretastatins A-4, A-5 and A-6. Journal of Medicinal Chemistry 38: 1666-1672.

25. Rayburn ER, Ezell SJ, Zhang R (2009) Anti-inflammatory agents for cancer therapy. Mol Cell Pharmacol 1: 29-43.

26. Davydova MP, Sorokina IV, Tolstikova TG, Mamatyuk VI, Fadeev DS, et al. (2015) Synthesis of new combretastatin A-4 analogues and study of their anti-inflammatory activity. Russian Journal of Bioorganic Chemistry 41: $70-76$

27. Pollock JK, Greene LM, Nathwani SM, Kinsella P, O'Boyle NM, et al (2018) Involvement of NF-kB in mediating the anti-tumour effects of com bretastatins in T cells. Invest New Drugs 36: 523-535.

28. Karatoprak GŞ, Akkol EK, Genç Y, Bardakci H, Yücel Ç, et al. (2020) Combretastatins: An overview of structure, probable mechanisms of action and potential applications. Molecules 25: 2560.

29. Liu S, Zheng Z, Ji S, Liu T, Hou Y, et al. (2018) Resveratrol reduces senescence-associated secretory phenotype by SIRT1/NF- $\kappa$ B pathway in gut of the annual fish Nothobranchius guentheri. Fish and Shellfish Immunol 80: 473-479.

30. Ginés C, Cuesta S, Kireev R, García C, Rancan L, et al. (2017) Protective effect of resveratrol against inflammation, oxidative stress and apoptosis in pancreas of aged SAMP8 mice. Experimental Gerontology 90: 61-70.

31. Rodríguez-Bies E, Tung BT, Navas P, López-Lluch G (2016) Resveratrol primes the effects of physical activity in old mice. Br J Nutr 116: 979-988.

32. Kan NW, Ho CS, Chiu YS, Huang WC, Chen PY, et al. (2016) Effects of resveratrol supplementation and exercise training on exercise performance in middle-aged mice. Molecules 21: 661

33. Issuree PD, Pushparaj PN, Pervaiz S, Melendez AJ (2009) Resveratrol attenuates $\mathrm{C} 5 \mathrm{a}$-induced inflammatory responses in vitro and in vivo by inhibiting phospholipase D and sphingosine kinase activities. FASEB J 23: 2412-2424.
34. Yang QB, He YL, Zhong XW, Xie WG, Zhou JG (2019) Resveratrol ameliorates gouty inflammation via upregulation of sirtuin 1 to promote autophagy in gout patients. Inflammopharmacology 27: 47-56.

35. Deng Z, Li Y, Liu H, Xiao S, Li L, et al. (2019) The role of sirtuin 1 and its activator, resveratrol in osteoarthritis. Biosci Rep 39: 20190189.

36. Custodero C, Mankowski RT, Lee SA, Chen Z, Wu S, et al. (2018) Evidence-based nutritional and pharmacological interventions targeting chronic low-grade inflammation in middle-age and older adults: A systematic review and meta-analysis. Ageing Res Rev 46: 42-59.

37. Rabassa M, Zamora-Ros R, Urpi-Sarda M, Bandinelli S, Ferrucci L, et al. (2015) Association of habitual dietary resveratrol exposure with the development of frailty in older age: The invecchiare in chianti study. Am J Clin Nutr 102: 1534-1542.

38. Franceschi C, Bonafe M, Valensin S (2000) Human immunosenescence: The prevailing of innate immunity, the failing of clonotypic immunity and the filling of immunological space. Vaccine 18: 1717-1720.

39. Yuan J, Lu L, Zhang Z, Zhang S (2012) Dietary intake of resveratrol enhances the adaptive immunity of aged rats. Rejuvenation Res 15: 507-515.

40. Palomera-Ávalos V, Griñán-Ferré C, Izquierdo V, Camins A, Sanfeliu C, et al. (2017) Metabolic stress induces cognitive disturbances and inflammation in aged mice: Protective role of resveratrol. Rejuvenation Res 20: 202-217.

41. Freeman LM (2012) Cachexia and sarcopenia: Emerging syndromes of importance in dogs and cats. J Vet Intern Med 26: 3-17.

42. Wilson D, Jackson T, Sapey E, Lord JM (2017) Frailty and sarcopenia: The potential role of an aged immune system. Ageing research reviews 36: $1-10$

43. Pastor RF, Restani P, Romero JE, Ferro EB, Serantes DR, et al. (2019) The supplementation with Resveratrol and $\alpha$-Tocopherol could reduce the risk of sarcopenia in dogs by counteracting the oxidative stress. Nutrition and Healthy Aging 5: 133-139.

44. Woode RA, Axiak-Bechtel SM, Tsuruta K, Amorim JR, Zhang Y, et al (2015) Resveratrol decreases oxidative burst capacity and alters stimulated leukocyte cytokine production in vitro. Veterinary immunology and immunopathology 163: 164-173.

45. Mathew LM, Woode RA, Axiak-Bechtel SM, Amorim JR, DeClue AE (2018) Resveratrol administration increases phagocytosis, decreases oxidative burst and promotes pro-inflammatory cytokine production in healthy dogs. Veterinary Immunol Immunopathol 203: 21-29.

46. Muzzio M, Huang Z, Hu SC, Johnson WD, McCormick DL, et al. (2012) Determination of resveratrol and its sulfate and glucuronide metabolites in plasma by LC-MS/MS and their pharmacokinetics in dogs. J Pharm Biomed Anal 59: 201-208.

47. Burnett K, Puschner B, Ramsey JJ, Lin Y, Wei A, et al. (2017) Lack of glucuronidation products of trans-resveratrol in plasma and urine of cats. Journal of animal physiology and animal nutrition 101: 284-292.

48. Spahn-Langguth H, Benet LZ (1992) Acyl glucuronides revisited: Is the glucuronidation process a toxification as well as a detoxification mechanism? Drug Metab Rev 24: 5-47.

49. Miyashita T, Kimura K, Fukami T, Nakajima M, Yokoi T (2014) Evaluation and mechanistic analysis of the cytotoxicity of the acyl glucuronide of nonsteroidal anti-inflammatory drugs. Drug Metabo Dispos 42: 1-8.

50. Cheng Y, Xue J, Yao C, Gao L, Ma D, et al. (2013) Resveratrol ameliorates the oxidative damage induced by arsenic trioxide in the feline lung. $J$ Vet Med Sci 75: 1139-1146.

51. Cheng Y, Xue J, Jiang H, Wang M, Gao L, et al. (2014) Neuroprotective effect of resveratrol on arsenic trioxide-induced oxidative stress in feline brain. Hum Exp Toxicol 33: 737-747. 
Citation: Tavener SK, Panickar KS (2020) Anti-Inflammatory Effects of Resveratrol and Related Polyphenols Contribute to their Potential Beneficial Effects in Aging. J Food Sci Nutr 6: 079.

52. Kaszubowska L, Foerster J, Kwiatkowski P, Schetz D (2018) NKT-like cells reveal higher than $\mathrm{T}$ lymphocytes expression of cellular protective proteins HSP70 and SOD2 and comparably increased expression of SIRT1 in the oldest seniors. Folia Histochem Cytobiol 56: 231-240.

53. Owczarz M, Budzinska M, Domaszewska-Szostek A, Borkowska J, Polosak J, et al. (2017) miR-34a and miR-9 are overexpressed and SIRT genes are downregulated in peripheral blood mononuclear cells of aging humans. Exp Biol Med (Maywood) 242: 1453-1461.

54. Kaysenm GA, Myers BD (1985) The aging kidney. Clinics in Geriatric Medicine 1: 207-222.

55. Anderson S, Brenner BM (1986) Effects of aging on the renal glomerulus. Am J Med 80: 435-442.

56. Denic A, Glassock RJ, Rule AD (2016) Structural and functional changes with the aging kidney. Adv Chronic Kidney Dis 23: 19-28.

57. Goyal VK (1982) Changes with age in the human kidney. Exp Gerontol 17: $321-331$.

58. Weinstein JR anderson S (2010) The aging kidney: Physiological changes. Adv Chronic Kidney Dis 17: 302-307.

59. Fried L, Solomon C, Shlipak M, Seliger S, Stehman-Breen C, et al. (2004) Inflammatory and prothrombotic markers and the progression of renal disease in elderly individuals. J Am Soc Nephrol 15: 3184-3191.

60. Vlassara H, Torreggiani M, Post JB, Zheng F, Uribarri J, et al. (2009) Role of oxidants/inflammation in declining renal function in chronic kidney disease and normal aging. Kidney Int Supp 114: 3-11.

61. Saldanha JF, Leal VO, Stenvinkel P, Carraro-Eduardo JC, Mafra D (2013) Resveratrol: Why is it a promising therapy for chronic kidney disease patients? Oxid Med Cell Longev 2013: 963217.

62. Abharzanjani F, Afshar M, Hemmati M, Moossavi M (2017) Short-term high dose of quercetin and resveratrol alters aging markers in human kidney cells. Int J Prev Med 8: 1-5.

63. Hsu SC, Huang SM, Chen A, Sun CY, Lin SH, et al. (2014) Resveratrol increases anti-aging Klotho gene expression via the activating transcription factor 3/c-Jun complex-mediated signaling pathway. Int J Biochem Cell Biol 53: 361-371.

64. Kuro-o M, Matsumura Y, Aizawa H, Kawaguchi H, Suga T, et al. (1997) Mutation of the mouse klotho gene leads to a syndrome resembling ageing. Nature 390: 45-51.

65. Koh N, Fujimori T, Nishiguchi S, Tamori A, Shiomi S, et al. (2001) Severely reduced production of klotho in human chronic renal failure kidney. Biochem Biophys Res Commun 280: 1015-1020.

66. Jang IA, Kim EN, Lim JH, Kim MY, Ban TH, et al. (2018) Effects of resveratrol on the renin-angiotensin system in the aging kidney. Nutrients 10: 1741

67. Ryu DR, Yu MR, Kong KH, Kim H, Kwon SH, et al. (2019) Sirt1-hypoxia-inducible factor- $1 \alpha$ interaction is a key mediator of tubulointerstitial damage in the aged kidney. Aging Cell 18: 1-12.

68. Sykiotis GP, Habeos IG, Samuelson AV, Bohmann D (2011) The role of the antioxidant and longevity-promoting Nrf2 pathway in metabolic regulation. Curr Opin Clin Nutr Metab Care 14: 41-48.

69. Kim EN, Lim JH, Kim MY, Ban TH, Jang IA, et al. (2018) Resveratrol, an Nrf2 activator, ameliorates aging-related progressive renal injury. Aging 10: 83-99.

70. Chang CC, Chang CY, Wu YT, Huang JP, Yen T, et al. (2011) Resveratrol retards progression of diabetic nephropathy through modulations of oxidative stress, proinflammatory cytokines and AMP-activated protein kinase. J Biomed Sci 18: 47.
71. Wong YT, Gruber J, Jenner AM, Ng MP, Ruan R, et al. (2009) Elevation of oxidative-damage biomarkers during aging in F2 hybrid mice: Protection by chronic oral intake of resveratrol. Free Radic Biol Med 46: 799-809.

72. Liu S, Zhao M, Zhou Y, Wang C, Yuan Y, et al. (2019) Resveratrol exerts dose-dependent anti-fibrotic or pro-fibrotic effects in kidneys: A potential risk to individuals with impaired kidney function. Phytomedicine 57: 223235

73. Saldanha JF, Leal VO, Rizzetto F, Grimmer GH, Ribeiro-Alves M, et al. (2016) Effects of resveratrol supplementation in Nrf2 and NF- $\kappa \mathrm{B}$ expressions in nondialyzed chronic kidney disease patients: A randomized, double-blind, placebo-controlled, crossover clinical trial. J Ren Nutr 26 : 401-406.

74. Weaver JD, Huang MH, Albert M, Harris T, Rowe JW, et al. (2002) Interleukin-6 and risk of cognitive decline: MacArthur studies of successful aging. Neurology 59: 371-378

75. Teunissen CE, van Boxtel MPJ, Bosma H, Bosmans E, Delanghe J, et al. (2003) Inflammation markers in relation to cognition in a healthy aging population. J Neuroimmunol 134: 142-150.

76. Heringa SM, van den Berg E, Reijmer YD, Nijpels G, Stehouwer CDA, et al. (2014) Markers of low-grade inflammation and endothelial dysfunction are related to reduced information processing speed and executive functioning in an older population-the Hoorn study. Psychoneuroendocrinology 40: 108-118.

77. Bourassa K, Sbarra DA (2017) Body mass and cognitive decline are indirectly associated via inflammation among aging adults. Brain Behav Immun 60: $63-70$

78. Trollor JN, Smith E, Agars E, Kuan SA, Baune BT, et al. (2011) The association between systemic inflammation and cognitive performance in the elderly: The Sydney memory and ageing study. Age (Dordr) 34: 12951308 .

79. Bettcher BM, Neuhaus J, Wynn MJ, Elahi FM, Casaletto KB, et al. (2019) Increases in a pro-inflammatory chemokine, $\mathrm{MCP}-1$, are related to decreases in memory over time. Front Aging Neurosci 11: 1-9.

80. Stenfors CU, Jonsdottir IH, Hanson LLM, Theorell T (2017) Associations between systemic pro-inflammatory markers, cognitive function and cognitive complaints in a population-based sample of working adults. Journal of Psychosomatic Research 96: 49-59.

81. Palomera-Ávalos V, Griñán-Ferré C, Izquierdo V, Camins A, Sanfeliu C, et al. (2018) Resveratrol modulates response against acute inflammatory stimuli in aged mouse brain. Exp Gerontol 102: 3-11.

82. Liu GS, Zhang ZS, Yang B, He W (2012) Resveratrol attenuates oxidative damage and ameliorates cognitive impairment in the brain of senescence-accelerated mice. Life Sci 91: 872-877.

83. Navarro-Cruz AR, Ayala RR, Ochoa-Velasco C, Brambila E, Avila-Sosa $R$, et al. (2017) Effect of chronic administration of resveratrol on cognitive performance during aging process in rats. Oxid Med Cell Longev 2017 8510761.

84. Calabrese F, Rossetti AC, Racagni G, Gass P, Riva MA, et al. (2014) Brain-derived neurotrophic factor: A bridge between inflammation and neuroplasticity. Front Cell Neurosci 8: 430.

85. Wiciński M, Malinowski B, Węclewicz MM, Grześk E, Grześk G (2017) Resveratrol increases serum BDNF concentrations and reduces vascular smooth muscle cells contractility via a NOS-3-independent mechanism. Biomed Res Int 2017: 9202954.

86. Yazir Y, Utkan T, Gacar N, Aricioglu F (2015) Resveratrol exerts anti-inflammatory and neuroprotective effects to prevent memory deficits in rats exposed to chronic unpredictable mild stress. Physiology \& Behavior 138: 297-304. 
87. Sun ZK, Ma XR, Jia YJ, Liu YR, Zhang JW, et al. (2014) Effects of resveratrol on apoptosis in a rat model of vascular dementia. Exp Ther Med 7: 843-848.

88. Nowak EC, de Vries VC, Wasiuk A, Ahonen C, Bennett KA, et al. (2012) Tryptophan hydroxylase-1 regulates immune tolerance and inflammation. J Exp Med 209: 2127-2135.

89. Sarubbo F, Ramis MR, Aparicio S, Ruiz L, Esteban S, et al. (2015) Improving effect of chronic resveratrol treatment on central monoamine synthesis and cognition in aged rats. Age 37: 9777.

90. Lin YT, Wu YC, Sun GC, Ho CY, Wong TY, et al. (2018) Effect of resveratrol on reactive oxygen species-induced cognitive impairment in rats with angiotensin II-induced early Alzheimer's disease. J Clin Med 7: 329.

91. Liu S, Li Y, Yi F, Liu Q, Chen N, et al. (2020) Resveratrol oligomers from Paeonia suffruticosa protect mice against cognitive dysfunction by regulating cholinergic, antioxidant and anti-inflammatory pathways. Journal of Ethnopharmacology 260: 112983.

92. Izquierdo V, Palomera-Ávalos V, López-Ruiz S, Canudas AM, Pallàs M, et al. (2019) Maternal resveratrol supplementation prevents cognitive decline in senescent mice offspring. Int J Mol Sci 20: 1134
93. Witte AV, Kerti L, Margulies DS, Flöel, A. (2014) Effects of resveratrol on memory performance, hippocampal functional connectivity and glucose metabolism in healthy older adults. J Neurosci 34: 7862-7870.

94. Turner RS, Thomas RG, Craft S, van Dyck CH, Mintzer J, et al. (2015) A randomized, double-blind, placebo-controlled trial of resveratrol for Alzheimer disease. Neurology 85: 1383-1391.

95. Evans H, Howe P, Wong R (2017) Effects of resveratrol on cognitive performance, mood and cerebrovascular function in post-menopausal women; a 14-week randomised placebo-controlled intervention trial. Nutrients 9:

96. Huhn S, Beyer F, Zhang R, Lampe L, Grothe J, et al. (2018) Effects of resveratrol on memory performance, hippocampus connectivity and microstructure in older adults-A randomized controlled trial. Neuroimage 174: $177-190$.

97. Yang Y, Jiang G, Zhang P, Fan J (2015) Programmed cell death and its role in inflammation. Mil Med Res 2: 12.

98. Farzaei MH, Rahimi R, Nikfar S, Abdollahi M (2018) Effect of resveratrol on cognitive and memory performance and mood: A meta-analysis of 225 patients. Pharmacol Res 128: 338-344. 


\section{H}

Advances In Industrial Biotechnology | ISSN: 2639-5665

Advances In Microbiology Research | ISSN: 2689-694X

Archives Of Surgery And Surgical Education | ISSN: 2689-3126

Archives Of Urology

Archives Of Zoological Studies | ISSN: 2640-7779

Current Trends Medical And Biological Engineering

International Journal Of Case Reports And Therapeutic Studies | ISSN: 2689-310X

Journal Of Addiction \& Addictive Disorders | ISSN: 2578-7276

Journal Of Agronomy \& Agricultural Science | ISSN: 2689-8292

Journal Of AIDS Clinical Research \& STDs | ISSN: 2572-7370

Journal Of Alcoholism Drug Abuse \& Substance Dependence | ISSN: 2572-9594

Journal Of Allergy Disorders \& Therapy | ISSN: 2470-749X

Journal Of Alternative Complementary \& Integrative Medicine | ISSN: 2470-7562

Journal Of Alzheimers \& Neurodegenerative Diseases | ISSN: 2572-9608

Journal Of Anesthesia \& Clinical Care | ISSN: 2378-8879

Journal Of Angiology \& Vascular Surgery | ISSN: 2572-7397

Journal Of Animal Research \& Veterinary Science | ISSN: 2639-3751

Journal Of Aquaculture \& Fisheries | ISSN: 2576-5523

Journal Of Atmospheric \& Earth Sciences | ISSN: 2689-8780

Journal Of Biotech Research \& Biochemistry

Journal Of Brain \& Neuroscience Research

Journal Of Cancer Biology \& Treatment | ISSN: 2470-7546

Journal Of Cardiology Study \& Research | ISSN: 2640-768X

Journal Of Cell Biology \& Cell Metabolism | ISSN: 2381-1943

Journal Of Clinical Dermatology \& Therapy | ISSN: 2378-8771

Journal Of Clinical Immunology \& Immunotherapy | ISSN: 2378-8844

Journal Of Clinical Studies \& Medical Case Reports | ISSN: 2378-8801

Journal Of Community Medicine \& Public Health Care | ISSN: 2381-1978

Journal Of Cytology \& Tissue Biology | ISSN: 2378-9107

Journal Of Dairy Research \& Technology | ISSN: 2688-9315

Journal Of Dentistry Oral Health \& Cosmesis | ISSN: 2473-6783

Journal Of Diabetes \& Metabolic Disorders | ISSN: 2381-201X

Journal Of Emergency Medicine Trauma \& Surgical Care | ISSN: 2378-8798

Journal Of Environmental Science Current Research | ISSN: 2643-5020

Journal Of Food Science \& Nutrition | ISSN: 2470-1076

Journal Of Forensic Legal \& Investigative Sciences | ISSN: 2473-733X

Journal Of Gastroenterology \& Hepatology Research | ISSN: 2574-2566
Journal Of Genetics \& Genomic Sciences | ISSN: 2574-2485

Journal Of Gerontology \& Geriatric Medicine | ISSN: 2381-8662

Journal Of Hematology Blood Transfusion \& Disorders | ISSN: 2572-2999

Journal Of Hospice \& Palliative Medical Care

Journal Of Human Endocrinology | ISSN: 2572-9640

Journal Of Infectious \& Non Infectious Diseases | ISSN: 2381-8654

Journal Of Internal Medicine \& Primary Healthcare | ISSN: 2574-2493

Journal Of Light \& Laser Current Trends

Journal Of Medicine Study \& Research | ISSN: 2639-5657

Journal Of Modern Chemical Sciences

Journal Of Nanotechnology Nanomedicine \& Nanobiotechnology | ISSN: 2381-2044 Journal Of Neonatology \& Clinical Pediatrics | ISSN: 2378-878X

Journal Of Nephrology \& Renal Therapy | ISSN: 2473-7313

Journal Of Non Invasive Vascular Investigation | ISSN: 2572-7400

Journal Of Nuclear Medicine Radiology \& Radiation Therapy | ISSN: 2572-7419

Journal Of Obesity \& Weight Loss | ISSN: 2473-7372

Journal Of Ophthalmology \& Clinical Research | ISSN: 2378-8887

Journal Of Orthopedic Research \& Physiotherapy | ISSN: 2381-2052

Journal Of Otolaryngology Head \& Neck Surgery | ISSN: 2573-010X

Journal Of Pathology Clinical \& Medical Research

Journal Of Pharmacology Pharmaceutics \& Pharmacovigilance | ISSN: 2639-5649

Journal Of Physical Medicine Rehabilitation \& Disabilities | ISSN: 2381-8670

Journal Of Plant Science Current Research | ISSN: 2639-3743

Journal Of Practical \& Professional Nursing | ISSN: 2639-5681

Journal Of Protein Research \& Bioinformatics

Journal Of Psychiatry Depression \& Anxiety | ISSN: 2573-0150

Journal Of Pulmonary Medicine \& Respiratory Research | ISSN: 2573-0177

Journal Of Reproductive Medicine Gynaecology \& Obstetrics | ISSN: 2574-2574

Journal Of Stem Cells Research Development \& Therapy | ISSN: 2381-2060

Journal Of Surgery Current Trends \& Innovations | ISSN: 2578-7284

Journal Of Toxicology Current Research | ISSN: 2639-3735

Journal Of Translational Science And Research

Journal Of Vaccines Research \& Vaccination | ISSN: 2573-0193

Journal Of Virology \& Antivirals

Sports Medicine And Injury Care Journal | ISSN: 2689-8829

Trends In Anatomy \& Physiology | ISSN: 2640-7752

Submit Your Manuscript: https://www.heraldopenaccess.us/submit-manuscript 